\author{
КОНФЕССИОНАЛЬНОЕ СОПРОВОЖДЕНИЕ \\ ПРЕПОДАВАНИЯ ПРАВОСЛАВНО-ОРИЕНТИРОВАННЫХ \\ ДИСЦИПЛИН В ШКОЛЕ \\ (РЕГИОНАЛЬНЫЙ АСПЕКТ)
}

\author{
Л. Н. УРБАНОВИЧ
}

\begin{abstract}
В статье обосновывается необходимость конфессионального сопровождения дисциплин духовно-нравственной и православной направленности в общеобразовательной школе. Автором отмечается, что конфессиональное сопровождение дисциплин с религиозным содержанием исторически обусловлено и предусмотрено современными нормативными правовыми документами и иными актами в сфере российского образования. На примере Смоленского региона показаны возможные направления конфессионального сопровождения со стороны православной религиозной организации. Описан опыт Смоленской Православной Духовной семинарии, оказывающей православно-конфессиональное сопровождение преподавания дисциплин с религиозным содержанием в регионе. В статье также намечены проблемные вопросы и возможные риски, требующие, по мнению автора, профессионального подхода к их разрешению.
\end{abstract}

До 1917 г. в России дело «душевного строения» и научение Закону Божьему были в ведении православного духовенства. Именно священнослужитель признавался главным лицом в религиозно-нравственном воспитании учащихся. В содержательном, методическом и практическом аспектах ситуация была далеко не идеальной из-за недостаточного уровня богословской, педагогической и психологической подготовленности законоучителя. Вместе с тем просвещение, окормление и забота о нравственной чистоте народа находились в зоне ответственности православной Церкви. В советский период не могло быть и речи о религиозном воспитании. Категорический запрет на упоминание религии, не говоря о ее присутствии в школе, последовал после Декрета «Об отделении церкви от государства и школы от церкви» 1918 г. И только в связи с демократическими процессами в обществе постсоветской России положение религии в стране кардинально изменилось, был открыт доступ к религиозным знаниям в образовательном пространстве школы.

С признанием свободы вероисповедания и мировоззренческого самоопределения появились вопросы теоретического и практического плана, связанные с преподаванием религиозных дисциплин. В настоящее время в нормативных документах и научно-педагогической литературе не определено содержание и 
Л. Н. Урбанович. Конфессиональное сопровождение преподавания...

не сформулирована дефиниция религиозного образования, наблюдается низкий уровень гуманитарной, общекультурной подготовки самих учителей, попрежнему дискуссионным остается вопрос о возможности и нужности присутствия в школах священнослужителей и пр. Учитель, осваивающий новый предмет, встречается с множеством различных трудностей содержательного, организационно-методического и мировоззренческо-этического плана. Поэтому конфессиональная помощь в реализации учебных курсов православной направленности со стороны религиозной организации в первую очередь должна быть направлена на преодоление указанных сложностей и предотвращение возможных рисков.

Прежде чем перейти к изложению системы конфессионального сопровождения преподавания православно-ориентированных дисциплин в Смоленском регионе, необходимо определиться с ключевыми понятиями. Сложившийся в науке понятийный аппарат сопровождения, педагогического сопровождения позволяют выделить важные компоненты описываемого процесса. Отметим лишь те из них, которые, на наш взгляд, позволяют раскрыть сущность конфессионального сопровождения. Под сопровождением понимается первичная помощь, установка на открытое общение в образовательном пространстве (В. И. Слободчиков), со-работничество (С. С. Хоружий); сопровождение выделяется как особая сфера деятельности, ориентированная на приобщение к культурным и нравственным ценностям (А. В. Мудрик); представляется как система профессиональной деятельности, направленная на создание условий успешного развития (М. Р. Битянова). По нашему мнению, конфессиональное сопровождение преподавания дисциплин с религиозным содержанием предполагает и открытый диалог православных организаций с педагогической и родительской общественностью, и особые виды деятельности (наблюдение, мониторинг, консультирование, личное участие, стимулирование) с целью выявления сути проблемы и поиска ее решения, и соответствующие меры, направленные на предотвращение существующих сложностей.

Все вышеперечисленные компоненты в результате оформляются в систему профессиональной помощи со стороны определенной конфессиональной образовательной организации. Таким образом, по нашему мнению, конфессиональное сопровождение - это профессиональная деятельность, которую систематически и последовательно осуществляет религиозная организация соответствующей конфессии в пространстве открытого диалога с образовательными структурами с целью создания оптимальных условий для преподавания религиозных дисциплин в школе.

В Смоленском регионе такую профессионально-конфессиональную помощь в реализации дисциплин с православным содержанием оказывает Смоленская Православная Духовная семинария. Конфессиональное сопровождение дисциплин с религиозным содержанием предусмотрено нормативными правовыми документами и иными актами в сфере образования ${ }^{1}$, в которых указаны

${ }^{1}$ См.: Письмо Министерства образования и науки России № 03-1584 от 13 июля 2007 г. об использовании примерного соглашения о сотрудничестве органа управления образованием субъекта Российской Федерации и централизованной религиозной организации 
виды и формы сотрудничества образовательных учреждений с религиозными организациями в решении следующих задач:

- обеспечение прав граждан на свободное и добровольное приобщение их детей к ценностям и традициям религиозной культуры в государственных и муниципальных общеобразовательных учреждениях с учетом законных интересов и прав представителей других религиозных организаций и нерелигиозной части общества;

- организация курсов повышения квалификации и (или) переподготовки педагогических работников общеобразовательных учреждений;

- проведение научно-практических и просветительских конкурсов, конференций и других мероприятий для обучающихся и педагогических работников, в том числе на базе религиозных организаций Русской Православной Церкви в субъекте РФ;

- анализ и обобщение опыта совместной работы в области образования, духовно-нравственного просвещения обучающихся, размещение информации о сотрудничестве в средствах массовой информации.

Федеральный закон «Об образовании в Российской Федерации» № 273-Ф3 от 29 декабря 2012 г. ${ }^{2}$ закрепляет за религиозными организациями право на:

- конфессиональную экспертизу примерных образовательных программ по курсе Основы религиозных культур и светской этики (ст. 87, ч. 3);

- участие централизованных религиозных организаций в учебно-методическом обеспечении курсов по ОРКСЭ и Теологии (ст. 87, ч. 6);

- получение образовательными организациями и педагогическими работниками общественной аккредитации в централизованных религиозных организациях в случае реализации ими образовательных программ с религиозным содержанием в целях признания уровня их деятельности, отвечающим критериям и требованиям, утвержденным централизованными религиозными организациями (ст. 87, ч. 12).

В письме Минобрнауки от 21.04.2014 № 08-516 «О реализации курса ОРКСЭ» имеется ссылка на материалы, которые расширяют область присутствия религиозных организаций в учебно-воспитательном процессе школы. В рекомендуемых методических материалах указаны следующие возможные формы взаимодействия с религиозными организациями: заключение соглашений (договоров) между религиозными организациями и образовательными учреждениями; участие в заседаниях методических объединений по оказанию помощи в религиозной части образовательной программы; участие в школьных мероприятиях духовно-нравственной и патриотической направленности; организация паломнических и экскурсионных поездок (с согласия родителей); участие в классных часах, беседах в качестве приглашенного гостя; в родительских

епархии Русской Православной Церкви. URL: http://base.consultant.ru/cons/cgi/online. cgi?req=doc;base=EXP;n=403467; Письмо директора Департамента государственной политики в образовании МОН РФ Реморенко И. М. № 03-1032 от 21 мая 2010 г. «В дополнение к методическим материалам по преподаванию ОРКСЭ». URL: http://www.k-istine.ru/opk/opk remorenko.htm; Письмо Министерства образования и науки от 21.04.2014 № 08-516 «О реализации курса ОРКСЭ». URL: http://www.orkce.org/494.htm; http://www.orkce.org/494.htm.

${ }^{2}$ URL: http://www.rg.ru/2012/12/30/obrazovanie-dok.html 
Л. Н. Урбанович. Конфессиональное сопровождение преподавания...

собраниях по выбору модуля; оказание помощи в обеспечении необходимой литературой духовно-нравственного содержания; консультирование со «служителем культа» в объяснении содержания учебного материала ${ }^{3}$.

Важным аспектом любого сопровождения является тот факт, что оно строится на результатах диагностики, учитывает общественные запросы и осуществляется в конкретных действиях. В большинстве случаев учителя, прошедшие курсовую подготовку (72 часа), оценивают уровень подготовленности к преподаванию курса «Основы религиозной культуры и светской этики» как достаточный. Однако, завершив годичный цикл преподавания, указывают на необходимость методического сопровождения, высказывают свои пожелания на проведение обучающих и практических семинаров, мастер-классов. Мониторинговые исследования родительской и педагогической общественности, наблюдение уроков, экспертиза поурочных разработок и методических материалов позволяют сделать определенные выводы о затруднениях, имеющихся у учителей, реализующих соответствующие дисциплины. Значительная часть учителей испытывают знаниевый дефицит в обращении с религиозной тематикой в школьном контексте, слабо осведомлены о методологических подходах преподавания дисциплин с религиозным компонентом, имеют недостаточный, если не сказать низкий, уровень владения современными интерактивными и активными методиками.

Как нам представляется, главная сложность заключается в том, что профессиональная педагогическая подготовка в советский и постсоветский периоды осуществлялась без учета религиозной составляющей в образовательном процессе, вследствие чего сегодня отмечается критически низкая профессиональная компетентность учителя, реализующего курс ОРКСЭ.

К сожалению, вопрос о профессиональной подготовке педагогических кадров к преподаванию предметов с религиозным содержанием пока остается на уровне дискуссий. В Смоленске только в педагогическом колледже введен курс «Методика преподавания комплексного курса ОРКСЭ». Преподаватели данной дисциплины указывают на проблемы, с которыми им пришлось встретиться: низкая мотивированность обучающихся; материал религиозного содержания воспринимается как экзотический, не имеющий отношения к окружающей их жизни; у большинства нет предварительных представлений общекультурного плана о том, что такое религия и какую роль она играет в обществе, они не осведомлены о сюжетах, мотивах библейской истории, которые вошли в историю литературы и искусства, стали частью мирового и национального достояния и др.

При этом, как отмечают преподаватели, реализующие данный курс, такое невежество среди будущих учителей начальной школы в вопросах религиозного знания нередко принимает протестные формы.

На уровне высшего профессионального образования ни в рамках бакалавриата, ни в магистратуре такая подготовка не осуществляется. Надо полагать, что это остается открытой перспективой для Смоленских вузов.

${ }^{3}$ См. сайт Департамента образования г. Москвы. URL: http://www.educom.ru/ru/works/ allschool/religion.php?sphrase_id=1614760 
В рамках договора, заключенного администрацией Смоленской области и Смоленской епархией, а также договора о сотрудничестве Смоленской Православной Духовной семинарии со Смоленским областным институтом развития образования, договоров о социальном партнерстве с образовательными учреждениями Смоленская семинария как аккредитованное учебное заведение осуществляет конфессиональное сопровождение по следующим основным направлениям:

1) курсовая подготовка учителей Православной культуры;

2) научно-методическая помощь в обеспечении дисциплин и курсов православной направленности;

3) экспертно-консультативная помощь учителям, методистам, тьюторам;

4) информационно-разъяснительная работа с родителями;

5) подготовка епархиальных специалистов, ответственных за религиозное образование.

Раскроем подробнее выделенные направления конфессионального сопровождения. Курсовая подготовка учителей осуществляется по программам «Комплексный курс “Основы религиозных культур и светской этики”». Модуль «Основы православной культуры», «Культурология. Православная культура».

Содержание курсовой подготовки по образовательным программам включает три блока. Теоретический блок ориентирован на восполнение знаниевого дефицита по религиозным, историко-культурным, теологическим вопросам. В программу включены основы православного вероучения, христианской нравственности, история Православия в истории Отечества, православное краеведение. Кроме предметной подготовки учителю, преподающему дисциплины с религиозным содержанием, не хватает «методологической и методической культуры», что сказывается в трудностях преподавания религиозных знаний в светской школе. Блок с общим названием «Методические аспекты преподавания религиозных дисциплин» в программах ориентирован на повышение уровня методической грамотности и освоение специальных подходов, форм и приемов работы с учебным материалом религиозного содержания с учетом положительного педагогического опыта в отечественной и мировой практике. Особое внимание уделяется активным и интерактивным методикам, которые способствуют личностному усвоению знаний, раскрытию ценностно-смысловой сферы учащихся. Практический блок ориентирован на формирование специализированных профессиональных компетенций и реализуется в таких формах, как мастер-классы, педагогические мастерские, экскурсионно-познавательные занятия в храме, диалог со священником, «круглый стол». Широко применяемые на практических занятиях интерактивные методические приемы помогают педагогу приобрести навык внимательного слушания другого человека, осмысления собственного опыта, личностного переживания, постижения традиции и соотнесения своего опыта с опытом другого человека.

В курсовой подготовке ключевым вопросом является кадровый. В настоящее время существует проблема принятия священника в качестве лектора курсов. Лектор-священник на курсах должен «расположить» аудиторию своей профессиональной компетентностью, общей эрудированностью и личными ка- 
Л. Н. Урбанович. Конфессиональное сопровождение преподавания...

чествами. Профессорско-преподавательский состав семинарии в этом вопросе отвечает предъявляемым требованиям, поэтому дисциплины богословского цикла читают священники-преподаватели семинарии. Большую же часть образовательной программы курсов подготовки и переподготовки учителей реализуют преподаватели семинарии, имеющие соответствующее образование и ученые степени в области гуманитарных наук.

Принимая во внимание краткосрочность курсов подготовки (72 часа, из них 14 выделено на модуль «Основы православной культуры») и имеющийся дефицит знаний, в поддержку учителю был разработан специальный раздел на сайте Смоленской семинарии, на котором размещены материалы нормативного, содержательного и методического характера, предназначенные как для самообразования учителя, так и для подготовки к урокам. Как показывает проведенный мониторинг, особо востребованными являются ссылки на электронные ресурсы, предлагающие методические рекомендации и разработки уроков.

Научно-методическая помощь выражается в проведении научно-практических конференций, педагогических чтений, разработке и издании методических рекомендаций, учебно- и научно-методических пособий ${ }^{4}$ В качестве предполагаемых результатов от использования указанной литературы, от научнопрактических мероприятий ожидаются: углубление теоретических знаний педагогов в области методики обучения религиозной тематике; расширение ценностно-смысловой сферы учителя через постижение глубины духовных смыслов православной культуры, национальной духовной традиции; повышение уровня методической и методологической культуры.

Чтобы избежать излишней дидактичности в прямом контакте с учителем при объяснении образовательно-воспитательных возможностей курса ОРКСЭ, были подготовлены специальные фильмы. Сюжеты видеороликов предназначены информировать учителя о целесообразности и важности преподавания основ религиозных знаний школьникам в новых социальных условиях. Знакомство с религиозной картиной мира в светской школе не является сегодня периферийным вопросом, связанным с интересами отдельных социальных групп - верующих, как это иногда представляется, а служит фундаментом формирования общекультурных компетенций обучающихся. В качестве демонстрационного материала к урокам Истории православной культуры земли Смоленской подготовлены учебные видеофильмы, которые знакомят с главными православными святынями Смоленского края, расширяют представление учащихся о культурноисторическом наследии малой Родины.

Экспертно-консультационная деятельность реализуется в таких видах, как экспертиза авторских рабочих программ и учебно-методических материалов

${ }^{4}$ Зыбина T. М. От слова к Слову. Интегрированное обучение религиозной лексике. Смоленск, 2014; Православная культура в общеобразовательной школе. Методические разработки и рекомендации к курсу / Л. Н. Урбанович, авт.-сост. Смоленск, 2010; Православное просвещение и духовно-нравственное воспитание в школе: теоретические аспекты и практический опыт: науч.-методическое пособие в помощь учителю / Л. Н. Урбанович, авт.-сост. Смоленск, 2014; Формирование духовно-нравственных ценностей у школьников на уроке и во внеурочной деятельности / Ж. В. Лукашенкова, авт.-сост. Смоленск, 2013. 
предметов православного компонента, рецензирование пособий, методических разработок, экспертиза и оценивание конкурсных учебных, методических, творческих материалов.

Консультационная помощь оказывается учителю при подготовке учебных материалов к урокам, в организации и проведении открытых занятий по Основам православной культуры в рамках методических объединений, в подготовке учебно-методических разработок, претендующих на участие в областных, межрегиональных и российских конкурсах.

Кроме обязательных курсов по подготовке (переподготовке) учителей, особое место занимают индивидуальные и групповые школьные, районные и областные методические консультации. Семинары-консультации призваны расширить полученные в рамках курсовой подготовки знания, оказать практическую помощь в реализации модуля «Основы православной культуры». Поэтому на консультациях-семинарах особое внимание уделяется проектированию уроков в соответствии с современными требования ФГОС, применению конкретных методов и приемов (например, приемы работы с евангельскими притчами, использование видео- и аудиоматериалов, иллюстраций на библейские сюжеты, использование межпредметной интеграции на уроках ОПК и др.).

Информационно-разбяснительная работа с родителями находится в зоне особого внимания специалистов Отдела по религиозному образованию. Среди имеющихся трудностей и проблем, связанных с введением в школе нового предмета «Основы религиозных культур и светской этики», следует отметить слабую мотивированность, низкую информированность родительской общественности и, как следствие, их неподготовленность к данному учебному предмету. Одним из приоритетных направлений в сопровождении курса ОРКСЭ со стороны образовательных институтов и религиозных организаций в настоящее время является систематическая и комплексная работа с родителями.

Согласно нормам Федерального Закона об образовании №273-Ф3 «в целях формирования и развития личности в соответствии с семейными и общественными духовно-нравственными и социокультурными ценностями получение знаний об основах духовно-нравственной культуры народов России, о нравственных принципах, об исторических и культурных традициях мировых религий осуществляется родителями или законными представителями на добровольной основе» $(87$, ст. 1$)$. Для обеспечения свободного, добровольного и ответственного выбора родителями учебного курса необходимо объективное, доступное, компетентное информирование. Основная задача информационноразъяснительной работы с родителями - создание установки на сотрудничество, а предполагаемый результат - мотивация и стимулирование заинтересованности родителей в позитивных результатах усвоения содержания курса их детьми.

Определенную помощь на этапе выбора модуля для принятия сознательного и ответственного решения могут оказать памятки, буклеты, видеоролики для родителей. Содержание учебного материала, представленное в лаконичной и наглядно-объяснительной форме, становится более доступным и может оказать содействие родителям с «латентной идентичностью» в определении их ценностно-смысловой и мировоззренческой позиции. 
Л. Н. Урбанович. Конфессиональное сопровождение преподавания...

Конфессиональное сопровождение родительских собраний по выбору и реализации модуля курса ОРКСЭ находится в зоне ответственности епархиальных специалистов Отдела по религиозному образованию и катехизации. Однако следует подчеркнуть, что им также необходима определенная подготовка, направленная на формирование умений и навыков владения не столько предметом разговора, сколько психолого-педагогическими методами и приемами.

Самое трудное для священнослужителя - выйти из «позиции проповедника» и вступить в «культурологический диалог» с аудиторией. В связи с этим в данном направлении осуществляется целенаправленная подготовка церковных специалистов в области просветительской и катехизической деятельности. Курсовая подготовка усилена блоком психолого-педагогических дисциплин, а регулярно проводимые методические семинары ориентированы на разъяснение вопросов нормативно-правового характера реализации религиозных дисциплин в школе, роли и места присутствия священнослужителя в образовательном пространстве.

Представляется необходимым остановиться и на принципиальных вопросах, требующих дальнейшей работы, а также на имеющихся рисках в реализации православно ориентированных дисциплин в школе.

Новый профессиональный стандарт педагога оставил без внимания профессионально специализированные компетенции учителя, реализующего предметы новой образовательной области «Духовно-нравственная культура народов России». Вместе с тем определенную помощь в данной сфере может оказать накопленный международный опыт. Преподавание религиозно ориентированных дисциплин по форме должно быть надконфессиональным и осуществляться с позиции культурологического подхода, но по содержанию оно всегда будет «внутри конфессиональной ограды». Поэтому видится оправданной двойная аккредитация как стороны Минобрнауки или Департамента образования, так и религиозной организации, чтобы учитель отвечал требованиям той конфессии, которую он будет представлять учащимся. В какой форме может быть представлена такая аккредитация, ещё предстоит определить.

Проблема конфессионального самоопределения учителя остается открытой. Нельзя не согласиться с О. В. Розиной, что «конфессиональное самоопределение учителя в системе подготовки к духовно-нравственному воспитанию школьников является фактором его профессионализма» ${ }^{5}$, однако дискуссионным остается вопрос о степени проявления своей конфессиональной идентичности. Достаточно ли для учителя религиозных дисциплин быть носителем православной культуры, знать и разделять основные положения православного вероучения, или это должен быть обязательно человек воцерковленный, требуется ли особое подтверждение его воцерковленности, например уведомления о том, как часто он исповедуется и причащается? К сожалению, эти вопросы встают на пути профессионального становления учителя. И очень личные стороны религиозной

${ }^{5}$ Розина О. В. Профессиональные компетенции и конфессиональное самоопределение педагога духовно-нравственных дисциплин в общеобразовательной школе // Православное просвещение и духовно-нравственное воспитание в школе: теоретические аспекты и практический опыт: науч.-метод. пособие в помощь учителю / Л. Н. Урбанович, авт.-сост. Смоленск, 2014. C. 22. 
жизни человека не только получают своего рода «презентацию и афиширование», но и формализуется, профанируется, обессмысливается истинная духовная жизнь человека.

В разъяснительных материалах о компетенциях учителя религиозных дисциплин отмечается, что учитель вправе отказаться по мировоззренческим причинам от преподавания данных дисциплин. Поэтому вопрос о специалисте, учителе-предметнике, реализующем дисциплины православной направленности в школе, сегодня является принципиальным.

Не представляется целесообразным массово готовить всех учителей начальной школы к преподаванию указанных дисциплин. Необходимо учитывать добровольное согласие, уровень профессиональной подготовки и конфессиональное представление или одобрение.

Нельзя оставить без внимания и обоснованные опасения некоторых специалистов и экспертов в области религиозного школьного образования, что «соприкосновение с религиозной тематикой повышает риск проявления таких педагогических злоупотреблений, как духовная экспансия, навязывание ребенку собственных представлений, нетерпимость к разномыслию, фанатизм, ханжество и проч. Эти злоупотребления могут спровоцировать возникновение конфликтных ситуаций на почве религиозных и мировоззренческих различий, чреватых широким спектром негативных социальных последствий» ${ }^{6}$. Профилактика указанных рисков и ошибок должна войти в область задач профессионального образования.

Таким образом, конфессиональное сопровождение преподавания православно ориентированных дисциплин в школе является не только актуальной задачей, но насущной потребностью сегодняшнего дня. Церковь в данном случае выступает своего рода гарантом соответствия содержания учебного материала и мировоззренческой позиции педагога православной культурной традиции. Чтобы конфессиональное сопровождение осуществлялось профессионально, уровень богословской, педагогической и психологической подготовки священно- и церковнослужителей должен быть соответствующим настоящим потребностям, уровню развития общества и современной науки.

В связи с этим понятно и объяснимо пристальное внимание священноначалия Русской Православной Церкви к подготовке специалистов в области просветительной, педагогической и катехизической деятельности. Сегодня важно не упустить исторический момент и изменить ситуацию с религиозным образованием в стране, но не с помощью катехизическо-дидактических методов, а через культурный, религиозно-мировоззренческий и ценностно-смысловой диалог всех участников образовательного процесса.

Ключевые слова: конфессиональное сопровождение, православно ориентированные дисциплины, профессиональная педагогическая подготовка, научнометодическая поддержка, экспертно-консультативная помощь, Смоленская Православная Духовная семинария.

6 Экспертное заключение на УМК «Духовно-нравственные беседы» (авт. Козырев Ф. Н. и др.). URL: http://school53spb.ru/store/school/documents/2014rzip.docx 
Л. Н. Урбанович. Конфессиональное сопровождение преподавания...

\section{CONFESSIONAL MAINTENANCE \\ OF TEACHING ORTHODOX ORIENTED SUBJECTS AT SCHOOL \\ (REGIONAL ASPECT)}

\section{URBANOVICH}

The necessity of confessional maintenance of moral and spiritual disciplines and Orthodox orientated disciplines at secondary school is justified in the article. The author notes that the confessional maintenance of disciplines with religious content is due historically and provided by modern legal documents and other acts in the field of Russian education. Certain possible directions of denominational maintenance conducted by Orthodox religious organization are shown by the example of Smolensk region. The experience of Smolensk Theological Seminary, rendering Orthodox confessional maintenance of teaching subjects with a religious content in the region, is presented as well. The article also identifies concerns and possible risks that require, in the author's opinion, a professional approach to their solution.

Keywords: confessional maintenance, Orthodox oriented disciplines, professional teacher training, scientific and methodological maintenance, expert advice, Smolensk Orthodox Theological Seminary.

\section{Список литературы}

1. Закон «Об образовании в Российской Федерации» № 273-Ф3 от 29.12.2012 г. URL: http://www.rg.ru/2012/12/30/obrazovanie-dok.html

2. Зыбина Т. М. От слова к Слову: интегрированное обучение религиозной лексике. Смоленск, 2014.

3. Письмо директора Департамента государственной политики в образовании МОН РФ Реморенко И. М. № 03-1032 от 21 мая 2010 г. «В дополнение к методическим материалам по преподаванию ОРКСЭ». URL: http://www.k-istine.ru/opk/opk_remorenko.htm

4. Письмо Министерства образования и науки от 21.04.2014 № 08-516 «О реализации курса OPКСЭ». URL: http://www.orkce.org/494.htm; http://www.orkce.org/494.htm.

5. Письмо Министерства образования и науки России № 03-1584 от 13 июля 2007 г. об использовании примерного соглашения о сотрудничестве органа управления образованием субъекта Российской Федерации и централизованной религиозной организации епархии Русской Православной Церкви. URL: http://base.consultant.ru/cons/cgi/ online.cgi? req $=$ doc; base $=\mathrm{EXP} ; \mathrm{n}=403467$

6. Православная культура в общеобразовательной школе. Методические разработки и рекомендации к курсу / Л. Н. Урбанович, авт.-сост. Смоленск, 2010.

7. Православное просвещение и духовно-нравственное воспитание в школе: теоретические аспекты и практический опыт: науч.-методическое пособие в помощь учителю / Л. Н. Урбанович, авт.-сост. Смоленск, 2014.

8. Розина О. В. Профессиональные компетенции и конфессиональное самоопределение педагога духовно-нравственных дисциплин в общеобразовательной школе // Православное просвещение и духовно-нравственное воспитание в школе: теоретические аспекты и практический опыт: науч.-метод. пособие в помощь учителю / Л. Н. Урбанович, авт.-сост. Смоленск, 2014. 
Исследования: педагогика

9. Сайт Департамента образования г. Москвы. URL: http://www.educom.ru/ru/works/ allschool/religion.php?sphrase_id= 1614760

10. Формирование духовно-нравственных ценностей у школьников на уроке и во внеурочной деятельности / Ж. В. Лукашенкова, авт.-сост. Смоленск, 2013.

11. Экспертное заключение на УМК «Духовно-нравственные беседы» (авт. Козырев Ф. Н. и др.). URL: http://school53spb.ru/store/school/documents/2014rzip.docx 